\title{
The FAACS backcast: Afforestation activity in the Prairie Provinces (1990-2002)
}

\author{
by R.J. Hall ${ }^{1,2}$ B.N. Joss ${ }^{1}$, D.M. Sidders ${ }^{1}$ and T.J. Keddy ${ }^{1}$
}

Under Action Plan 2000, the Feasibility Assessment of Afforestation for Carbon Sequestration (FAACS) initiative is exploring the feasibility of large-scale afforestation as an effective response to Canada's climate change commitments. One component of the FAACS initiative is a "backcast" or inventory of afforestation activity that has occurred on privately owned land since 1990. Within the Prairie Provinces, the backcast of afforestation activity identified approximately 2650 hectares that were afforested between 1990 and 2002. Temporal and spatial trends were identified from the afforestation activities documented. Temporally, there was a two-year cycle of afforestation activity between 1997 and 2002, and a noticeable shift from the planting of coniferous to deciduous trees between 2000 and 2001. Spatially, three ecoregions, Boreal Transition, Mid-Boreal Uplands and Peace Lowland, accounted for $83 \%$ of the afforestation activity. Environmental conditions associated with afforestation sites were identified for mean annual and growing season precipitation (342 $\mathrm{mm}$ to $578 \mathrm{~mm}$ and $214 \mathrm{~mm}$ to $361 \mathrm{~mm}$, respectively), climate moisture index (-27 to $20 \mathrm{~cm}$ ), and growing degree days (1009 to 1789). Afforestation sites were mostly located on loamy, well-drained soils with pH values between 6 and 8 in plant hardiness zones 1a, 1b, 2a, 2b and 3a. Environmental and socioeconomic (e.g., proximity to mills) factors influenced the location of afforestation activity in the Prairie Provinces. This information provides direct inputs into the selection of spatial and environmental variables and their attribute values for developing a model of land suitability for afforestation in the Prairie Provinces, and will provide a basis for its application across Canada.

Key words: afforestation, reforestation, land suitability, carbon sequestration, hybrid poplar

En vertu du Plan d'action 2000, le projet d'évaluation de la faisabilité du boisement à des fins de séquestration du carbone explore la faisabilité d'un boisement à grande échelle en tant que mesure efficace dans le cadre des engagements du Canada en matière de changements climatiques. Un élément de cette initiative consiste en un « répertoire » ou un inventaire des activités de boisement entreprises sur les terrains privés depuis 1990. Dans les Provinces des Prairies, le répertoire d'activités de boisement a identifié environ 2650 hectares qui ont été boisés entre 1990 et 2002. Les tendances temporelles et spatiales ont été identifiées à partir des activités de boisement documentées. Au niveau temporel, il y a eu deux cycles d'activités de boisement entre 1997 et 2002, ainsi qu'un passage notable de la plantation de conifères à celle de feuillus entre 2000 et 2001. Au niveau spatial, trois écorégions, Boreal Transition, Mid-Boreal Uplands et Peace Lowland, totalisaient $83 \%$ des activités de boisement. Les conditions environnementales associées aux sites de boisement ont été identifiées pour ce qui est des précipitations annuelles moyennes et des précipitations au cours de la saison de croissance (respectivement de $342 \mathrm{~mm}$ à $578 \mathrm{~mm}$ et de $214 \mathrm{~mm}$ à $361 \mathrm{~mm}$ ), de l'indice d'humidité climatique (de -27 à $20 \mathrm{~cm}$ ), ainsi que pour le nombre de degrés-jours de croissance (de 1009 à 1789). Les sites de boisement étaient principalement localisés sur des sols loameux et bien drainés ayant un $\mathrm{pH}$ se situant entre 6 et 8 dans les zones de rusticité $1 \mathrm{a}, 1 \mathrm{~b}, 2 \mathrm{a}, 2 \mathrm{~b}$ et $3 \mathrm{a}$.Les facteurs environnementaux et socioéconomiques (par, ex., la proximité des usines) ont influencé la localisation des activités de boisement dans les Provinces des Prairies. Cette information apporte une contribution directe au niveau de la sélection des variables spatiales et environnementales ainsi que des valeurs qui leur sont attribuées dans le cadre de l'élaboration d'un modèle de disponibilités des terrains à des fins de boisement dans les Provinces des Prairies et constituera une base pour son application partout au Canada.

Mots-clés : boisement, reboisement, disponibilité des terrains, séquestration du carbone, peuplier hybride

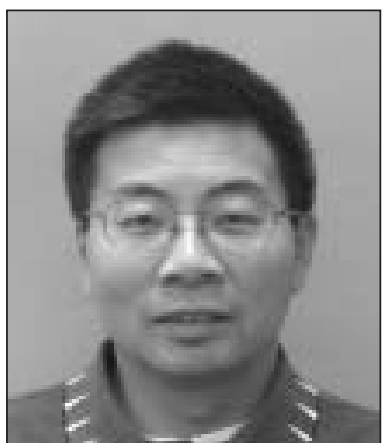

R.J. Hall

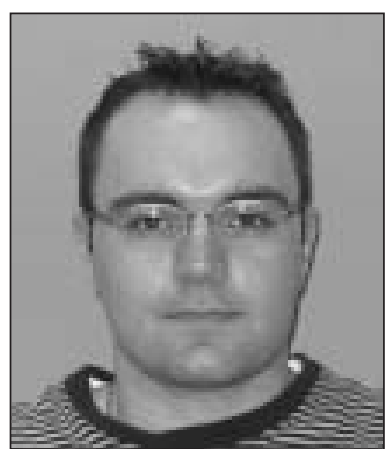

B.N. Joss

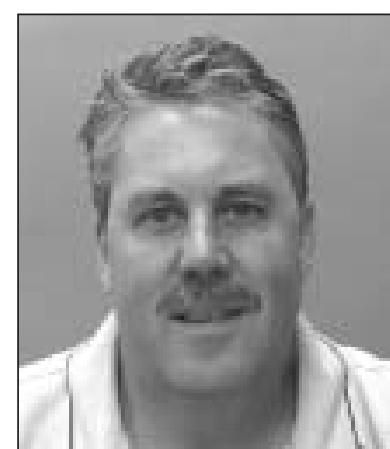

D.M. Sidders

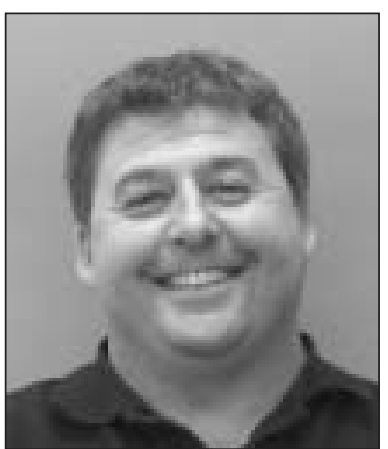

T.J. Keddy

${ }^{1}$ Canadian Forest Service, Northern Forestry Centre, 5320-122 Street, Edmonton, Alberta, T6H 3S5.

${ }^{2}$ Corresponding author. E-mail: Ron.Hall@nrcan-rncan.gc.ca 


\section{Introduction}

In the October 6, 2000 announcement of the "Government of Canada Action Plan 2000 on Climate Change," an investment of \$500 million over five years was announced to develop specific measures that reduce greenhouse gas emissions and promote carbon sequestration opportunities. Action Plan 2000 aimed to target a number of key sectors in transportation, energy, industry, agriculture, and forestry, and provided several measures that could help Canada achieve up to one-third of its Kyoto Protocol emission reduction target during the 2008 to 2012 commitment period. The forestry component of Action Plan 2000 was focused on studying carbon sequestration opportunities through the Feasibility Assessment of Afforestation for Carbon Sequestration (FAACS) initiative.

The FAACS initiative is exploring the feasibility of largescale afforestation/reforestation ${ }^{3}$ activities (now referred to as afforestation) as an effective response to Canada's climate change commitments. The main focus was to carry out information collection and land assessment research on privately owned lands as well as help set up the required carbon measurement and accounting infrastructure to support Canada's Kyoto Protocol reporting requirements. The Kyoto Protocol permits countries to enhance their carbon sinks and to obtain limited credits for sequestering carbon to meet their Kyoto commitments. Article 3.3 of the Kyoto Agreement requires that changes in greenhouse gas emissions by sources and sinks be reported in national carbon inventory estimates. Countries are therefore obligated to account for their afforestation, reforestation, and deforestation activities that have occurred since 1990 as a basis to measure verifiable changes in carbon stocks during each commitment period (United Nations Framework Convention on Climate Change 2004).

The backcast component of the FAACS initiative is being undertaken across Canada to help address the accounting requirements described by the Kyoto Agreement. This study focuses on the Prairie Provinces backcast, by documenting and analyzing afforestation activity through area-based plantings that had occurred on private lands since 1990. The purpose of this paper is to a) summarize the afforestation activities from the Prairie Provinces during 1990 to 2002; and b) describe the environmental characteristics at the afforestation sites. Future work into assessing the feasibility of large-scale afforestation within this region will depend on a land suitability model that will be based on results derived from this study.

\section{Methods}

\section{Afforestation data collection}

The afforestation site data that were collected and compiled consisted of area-based afforestation event information for the Prairie Provinces between 1990 and 2002, and included a) site infor-

\footnotetext{
${ }^{3}$ Afforestation is defined through the Marrakech Accord as the direct humaninduced conversion of land that has not been forested for a period of 50 years to forested land through planting, seeding and/or the human-induced promotion of natural seed sources. Reforestation is the direct human-induced conversion of non-forested land to forested land through planting, seeding and/ or human-induced promotion of natural seed sources on land that was forested but that has been converted to non-forest land. For the first commitment period, reforestation activities will be limited to reforestation occurring on those lands that did not contain forest on 31 December 1989. The FAACS initiative primarily focused on private lands that were not previously forested but were forested after December 31, 1989
}

Table 1. List of environmental datasets associated with the afforestation field data

\begin{tabular}{c} 
Environmental dataset \\
\hline Annual precipitation \\
Growing Season Precipitation \\
Climate Moisture Index \\
Growing Degree Days \\
Canada Land Inventory Capability for Agriculture \\
Plant hardiness \\
Elevation \\
Soil drainage \\
Soil pH \\
Soil texture \\
Land Cover
\end{tabular}

mation such as: geographic location, legal description and detailed site plans; b) plantation characteristics such as tree spacings, row counts, plantation dimensions, and photographs; and c) tree data in the form of average tree height and diameter at breast height (dbh) measurements. Information about plantings provided by the private land owner was verified in the field at virtually all of the afforestation sites.

\section{Backcast analytical methods}

Analytical methods were developed both to analyze past afforestation activity and to provide preliminary information to help assess the feasibility of large-scale afforestation in Canada. Temporal, spatial and composition information about afforestation activities in the Prairie Provinces were derived by a) acquiring, organizing and manipulating afforestation and environmental datasets; b) summarizing data; c) spatial overlay analysis; and d) generating graphical outputs.

Afforestation site data (e.g., hectares planted) were summarized into six species or species groups that included hybrid aspen (Populus spp.), hybrid poplar (Populus spp.), lodgepole pine (Pinus contorta Dougl. Ex Loud. var. latifolia Engelm.), white spruce (Picea glauca (Moench) Voss), "other deciduous" and "other coniferous." The resultant database was organized into a "flat file" format and imported into the ESRI Arc/Info Geographic Information System (GIS). Afforestation sites were then geocoded, or assigned geographic coordinates, using the township fabric for the Prairie Provinces and converted to a spatial data format. The resulting spatial coverage of afforestation activities was then overlaid in the GIS with environmental datasets depicting topography (Farr and Kobrick 2000, Rabus et al. 2003), hydrography, terrestrial ecozones (Ecological Stratification Working Group 1995), major cities/towns, and major mill sites, to identify and interpret any apparent spatial trends. The terrestrial ecozones dataset was selected to spatially summarize or stratify the afforestation data. The summarized area-based afforestation data for the Prairie region were graphed and mapped to yield information pertaining to temporal activity, spatial distribution, and composition of afforestation activities.

A selected set of environmental datasets was spatially overlaid with the afforestation data to determine the environmental conditions at each of the afforestation sites (Table 1). The following environmental variables were selected based on their reported influence on tree growth: precipitation (Bibby et al. 1988, Gosz and Sharpe 1989); moisture deficit (Hogg 1994, 1997; Schroeder 1998); temperature and growing degree days 


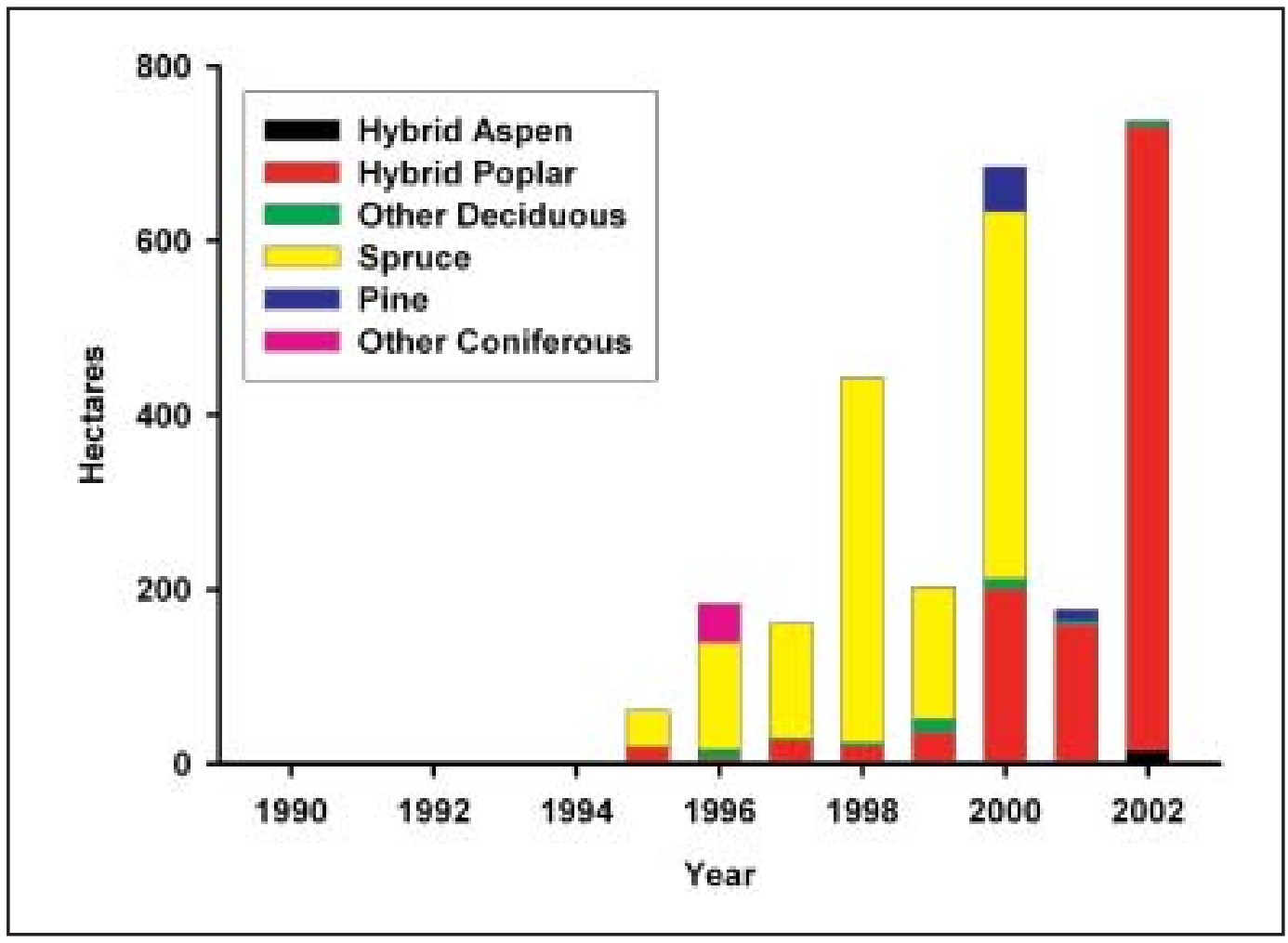

Fig. 1. Afforestation trends in Prairie Provinces by species in 1990-2002.

(Oullet and Sherk 1967, Bibby et al. 1988, Kimmins 1997); soil drainage, texture and $\mathrm{pH}$ (Baker and Broadfoot 1979, Bibby et al. 1988, Gosz and Sharpe 1989, Kimmins 1997 , Schroeder et al. 2003), plant hardiness (Oullet and Sherk 1967, McKenney et al. 2001), and elevation (Bibby et al. 1988, Schroeder et al. 2003).

The analysis of environmental conditions associated with afforestation sites was undertaken in two stages. First, a spatial overlay approach was implemented to relate afforestation sites with a suite of environmental variables. Next, zonal statistics (i.e., descriptive statistics) were calculated for a $20-\mathrm{km}$ radius around each afforestation site. Minimum, maximum, mean and mode values for each environmental variable were computed to describe the general environmental conditions at each afforestation site. Minimum, maximum and mean values were calculated for continuous (i.e., interval/ratio) datasets whereas majority (i.e., mode) values were determined for nominal, or classified datasets.

\section{Results}

\section{Afforestation activity: Prairie Provinces}

There was no record of afforestation activity within the Prairie Provinces until 1993, and from 1993 to 2002 there was no apparent increasing or decreasing trend in magnitude of afforestation (Fig. 1). Two temporal trends were observed. The first was a relative peak in afforestation activity every second year whereby 1998, 2000, and 2002 were years of relatively high activity (Fig. 1). These three years accounted for $70 \%$ of the overall area afforested during the 1993 to 2002 period. The second temporal trend was a shift from coniferous to deciduous tree species during 2000-2001. This shift was first observed in 2001 and by 2002 deciduous species accounted for all of the afforestation activity in the Prairie Provinces.
Table 2. Area of afforestation by species in each of the Prairie Provinces during 1990 to 2002

\begin{tabular}{|c|c|c|c|c|c|c|c|}
\hline \multirow[t]{2}{*}{ Species } & \multicolumn{2}{|c|}{ Alberta } & \multicolumn{2}{|c|}{ Saskatchewan } & \multicolumn{2}{|c|}{ Manitoba } & \multirow{2}{*}{$\begin{array}{r}\text { Prairies } \\
\text { Total }\end{array}$} \\
\hline & На & $\%$ & ha & $\%$ & ha & $\%$ & \\
\hline $\begin{array}{r}\text { Hybrid } \\
\text { aspen }\end{array}$ & 18.7 & 82 & 0.8 & 3 & 3.8 & 15 & 22.9 \\
\hline $\begin{array}{l}\text { Hybrid } \\
\text { poplar }\end{array}$ & 835.2 & 71 & 214.9 & 18 & 133.0 & 11 & 1183.1 \\
\hline $\begin{array}{l}\text { Other } \\
\text { deciduous }\end{array}$ & 40.9 & 75 & 13.3 & 25 & - & - & 54.2 \\
\hline Spruce & 1282.8 & 100 & - & - & - & - & 1282.8 \\
\hline Pine & 48.6 & 76 & 15.1 & 24 & - & - & 63.7 \\
\hline $\begin{array}{l}\text { Other } \\
\text { coniferous }\end{array}$ & 43.5 & 100 & - & - & - & - & 43.5 \\
\hline Total & 2269.4 & 86 & 244.1 & 9 & 136.8 & 5 & 2650.2 \\
\hline
\end{tabular}

From the backcast database, approximately 2650 hectares were afforested on privately owned lands between 1993 and 2002. The Province of Alberta accounted for $86 \%$ of the afforested land in the Prairie region, followed by Saskatchewan (9\%) and Manitoba (5\%) (Table 2). Overall, white spruce and hybrid poplar species accounted for $93 \%$ (approximately 2466 ha) of the land base afforested (Table 2).

Where were the Prairie region afforestation activities concentrated? Much of the afforestation activity between 1993 and 2002 was concentrated in central Alberta, central and southeastern Saskatchewan and southern Manitoba (Fig. 2). In addition, $95 \%$ of the afforestation activity occurred in five ecoregions: Aspen Parkland, Western Upland, Boreal Transition, MidBoreal Uplands and Peace Lowland (Fig. 2), with the latter three accounting for approximately $83 \%$ of this activity (Fig. 3 ). 


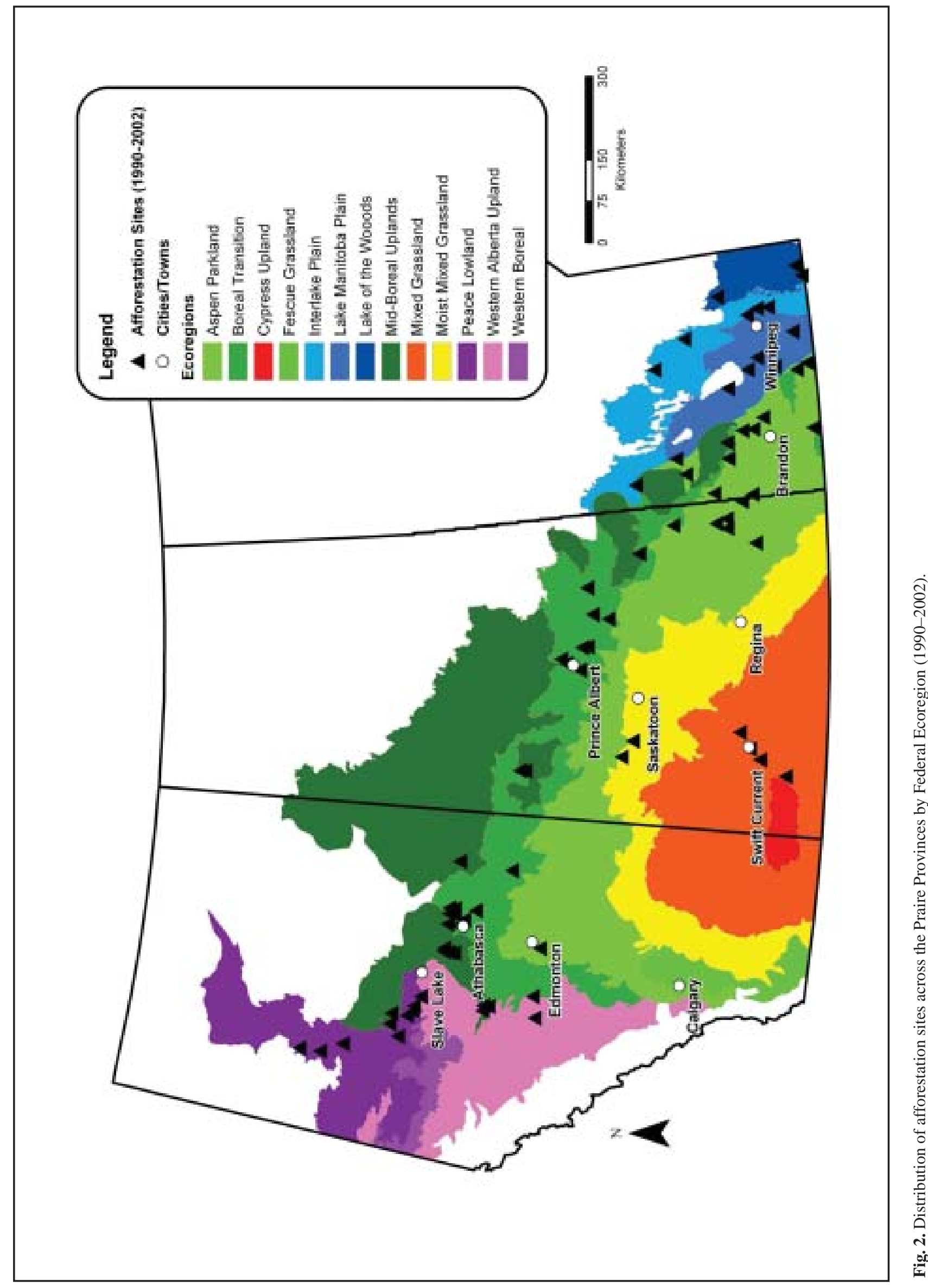




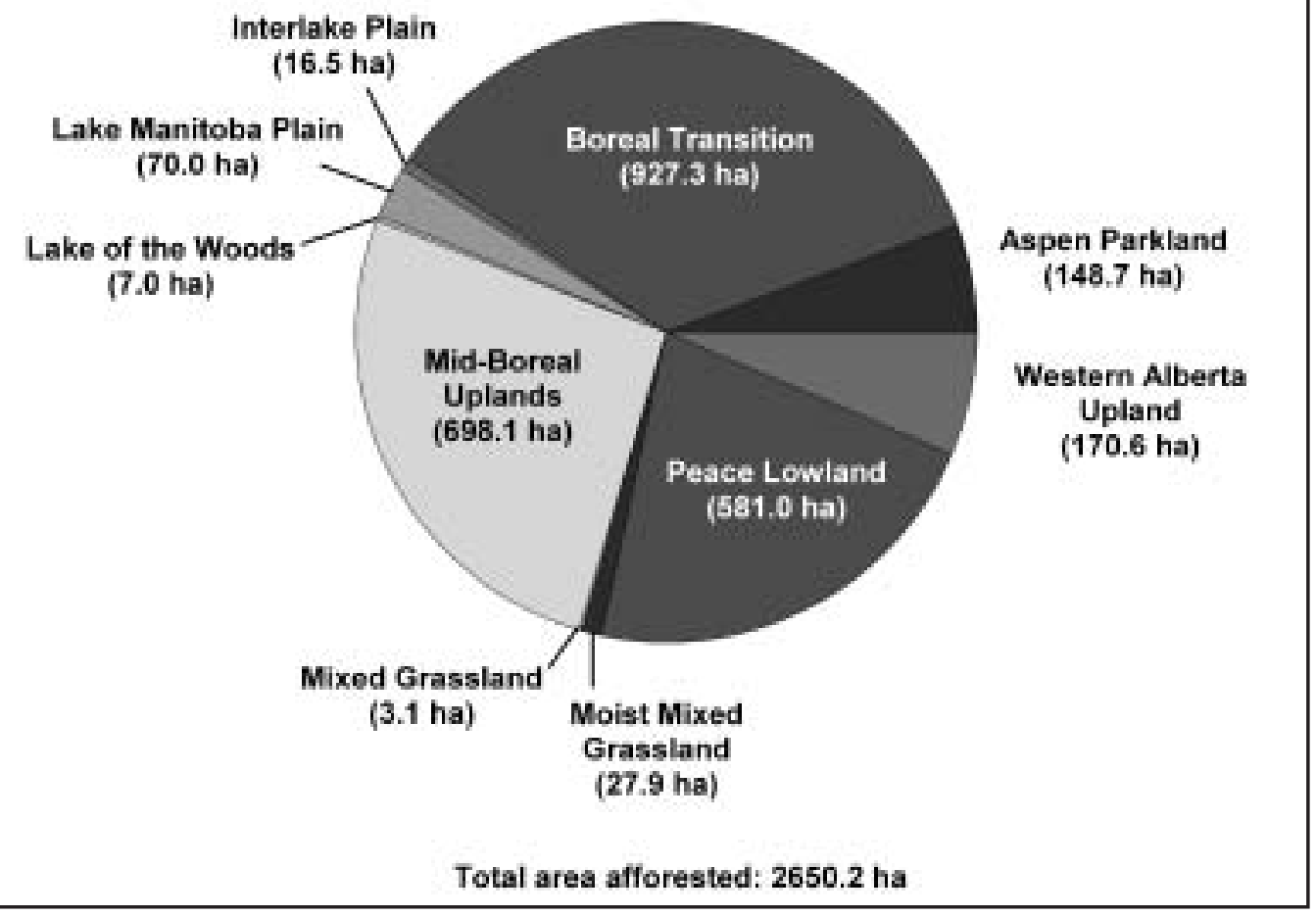

Fig. 3. Composition of afforestation across the Prairie Provinces by terrestrial ecoregion.

\section{Afforestation activity: Alberta}

Given that Alberta accounted for $86 \%$ of the afforestation activity occurring in the Prairie Provinces since 1990, the afforestation picture within the province dominated the pattern observed for the region. With the exception of a two-year cycle in activity and a noticeable shift in the planting of coniferous (i.e., white spruce) to deciduous (i.e., hybrid poplar), there was no definitive temporal trend in afforestation activities.

White spruce and hybrid poplar accounted for $93 \%$ of the 2269 hectares planted in the province (Table 2) between 1993 and 2002. 1998, 2000 and 2002 were years of relatively high afforestation activity, accounting for approximately $75 \%$ of the total afforestation activity in Alberta between 1993 and 2002 (Fig. 4).

Much of the afforestation activity between 1993 and 2002 was limited to central Alberta and concentrated in the vicinity of Athabasca, Whitecourt and Lesser Slave Lake (Fig. 2). Afforestation activity largely occurred in five eco-regions: Peace Lowland, Western Alberta Upland, Boreal Transition, Mid-Boreal Uplands, and Aspen Parkland. With the exception of the Western Alberta Upland and Aspen Parkland, the other three ecoregions accounted for the majority $(92 \%)$ of the afforestation activity occurring in the province (Fig. 5).

\section{Afforestation activity: Saskatchewan}

Approximately 244 hectares were considered afforestation on privately-owned lands in Saskatchewan between 1993 and 2002, and during this period there were no definitive temporal trends in afforestation activities (Table 2, Fig. 4). Hybrid poplar accounted for $88 \%$ of the land afforested in the province, and Saskatchewan was the only province, other than Alberta, to have land afforested with coniferous tree species (Table 2).

Afforestation activity between 1997 and 2002 was concentrated in central and southeastern Saskatchewan, with notable clusters around Prince Albert and Esterhazy. Within these areas, $93 \%$ of afforestation activity occurred in three ecoregions: Boreal Transition, Aspen Parkland, and Moist-Mixed Grassland, with the latter two accounting for approximately $81 \%$ of the total activity in the province (Fig. 5).

\section{Afforestation activity: Manitoba}

Approximately 137 hectares were afforested on privatelyowned lands in Manitoba between 1996 and 2002. Hybrid poplar species accounted for $97 \%$ (approximately $133 \mathrm{ha}$ ) of the afforested land base (Table 2). Afforestation activity within Manitoba commenced in 1996, and the average annual area afforested from 2000 to 2002 was more than double the average area afforested during 1996 to 1999 (Fig. 4). Seventy-six per cent of the overall area afforested in Manitoba occurred between 2000 and 2002.

All of the afforestation activity was concentrated in southern Manitoba with much of the activity near Brandon and Portage la Prairie (Fig. 2). Most of the afforestation activity (95\%) occurred in four ecoregions: Lake Manitoba Plain, Aspen Parkland, Boreal Transition, and Interlake Plain, with the Lake Manitoba Plain ecoregion accounting for approximately $50 \%$ of the activity in the province (Fig. 5).

Environmental conditions associated with afforestation Table 3 presents the range of values for the environmental variables associated with afforestation sites in the Prairie region from which the following observations were derived:

\section{Climatic conditions}

Afforestation sites in the Prairie region were characterized by mean annual and mean growing season precipitation levels of $476 \mathrm{~mm}$ and $295 \mathrm{~mm}$, respectively. Mean annual precipitation ranged between $342 \mathrm{~mm}$ and $578 \mathrm{~mm}$, and growing season pre 


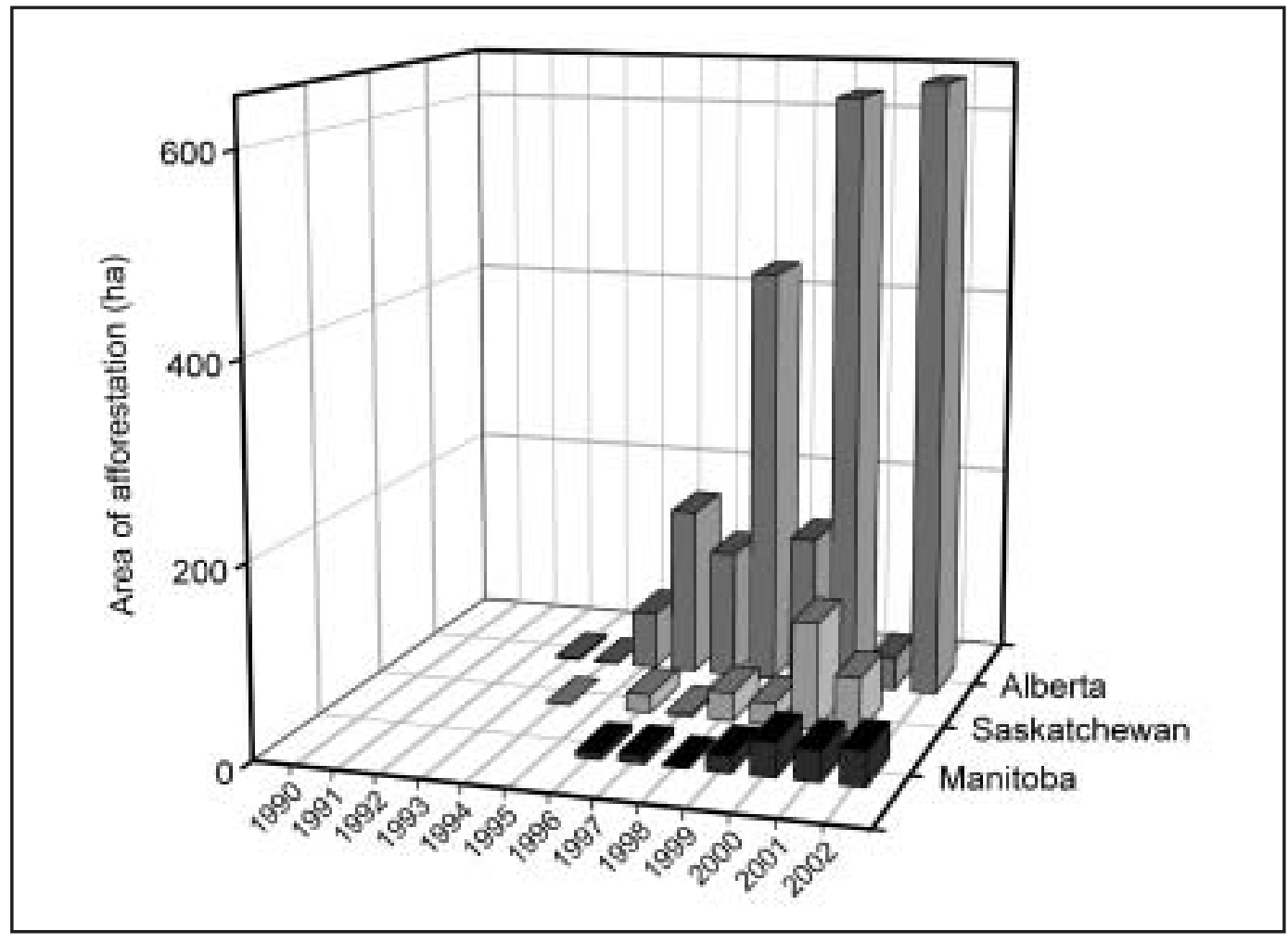

Fig. 4. Area of afforestation by year in the Prairie Provinces between 1990 and 2002.

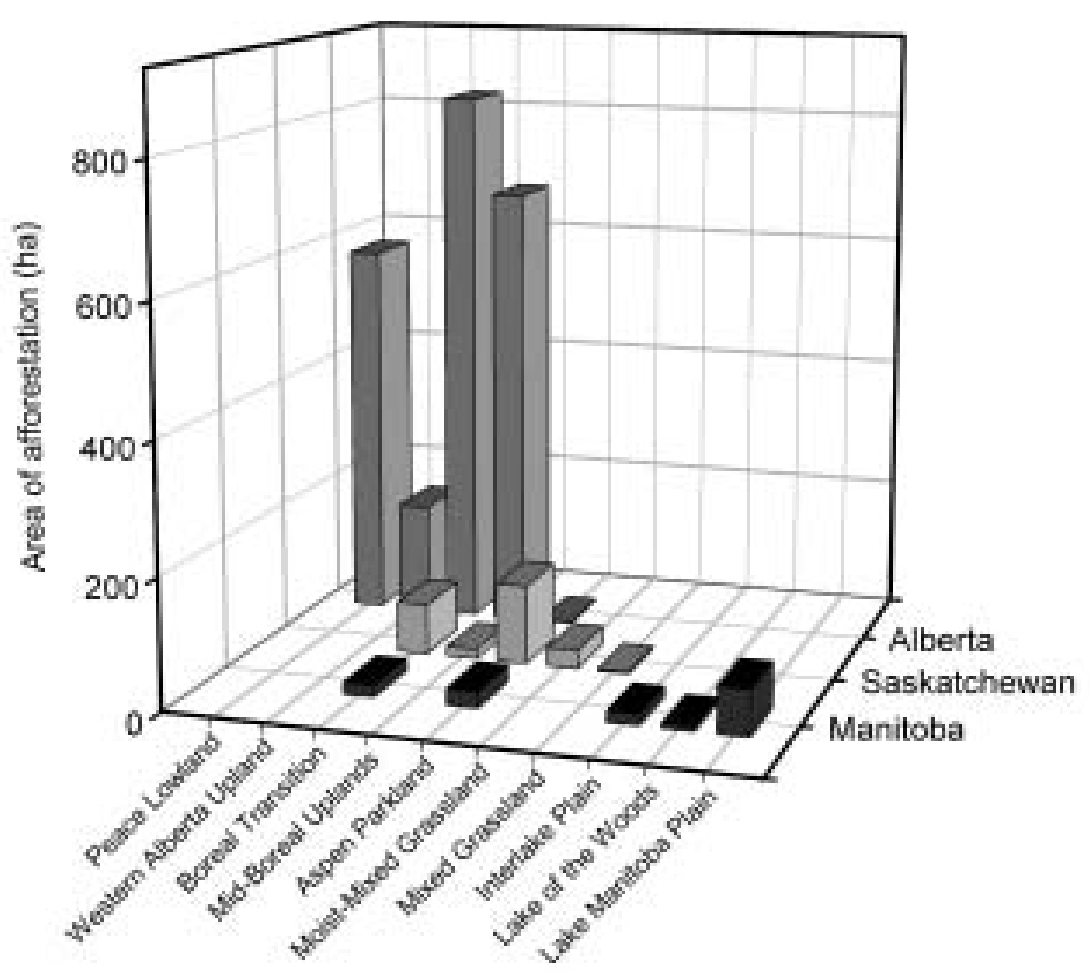

Fig. 5. Area of afforestation by Terrestrial Ecoregion in the Prairie Provinces between 1990 and 2002. 


\begin{tabular}{lccc}
\hline Table 3. Environmental values at afforestation sites & \\
\hline Environmental Variable & Minimum & Maximum & $\begin{array}{c}\text { Mean/ } \\
\text { Majority }\end{array}$ \\
\hline Annual precipitation & 342 & 578 & 476 \\
Growing Season Precipitation & 214 & 361 & 295 \\
Climate Moisture Index & -27.3 & 19.6 & 5.2 \\
Growing Degree Days & 1009 & 1789 & 1314 \\
Canadian Land Inventory (Ag.) & 1 & 7 & 3 \\
Soil drainage & N/A & N/A & Well \\
Soil texture & N/A & N/A & Loam \\
Soil pH & 5.4 & 7.9 & 6.4 \\
Plant hardiness & 9 & 32 & 21 \\
Elevation & 237 & 950 & 563 \\
Land cover & N/A & N/A & Herb- \\
& & & dominated \\
\hline
\end{tabular}

cipitation amounts ranged from $214 \mathrm{~mm}$ to $361 \mathrm{~mm}$. These values were considered within the optimal range for growth and establishment of hybrid poplar (Schroeder et al. 2003). Climate Moisture Index (CMI) values associated with afforestation sites varied considerably, ranging from $-27.3(\mathrm{~cm})$ to $19.6(\mathrm{~cm})$. The average CMI was 5.2, a value that minimally falls into the intermediate zone as values less than 5 are considered dry (Brandt et al. 2003). Growing degree-days averaged 1314 and ranged from 1009 to 1789 . Given that plant hardiness values that range from 0 to 100 with the larger number representing more mild growing conditions (McKenney et al. 2001), values for afforestation sites were on the lower end of the scale between 9 and 32, and this corresponded to plant hardiness zones $1 \mathrm{a}, 1 \mathrm{~b}, 2 \mathrm{a}, 2 \mathrm{~b}$ and $3 \mathrm{a}$. The average plant hardiness value was 21 , or zone $2 \mathrm{a}$.

\section{Edaphic conditions}

Soil texture, drainage, and $\mathrm{pH}$ were derived from the Soil Landscapes of Canada (Agriculture and Agri-Foods Canada 2004), for which soil texture information was only available for $60 \%$ of the afforestation sites. Based on this information, soil textures ranged from clay loam to gravelly sand, and $66 \%$ of the afforestation sites occurred on loamy soils (Fig. 6). Drainage ranged from imperfect to rapid with most of the afforestation sites $(56 \%)$ occurring on well-drained soils (Fig. 7). Prairie afforestation sites were also characterized by soil $\mathrm{pH}$ values ranging from 5.4 to 7.9, with an average soil $\mathrm{pH}$ value of 6.4. Approximately $90 \%$ of the afforestation sites were recorded with soil $\mathrm{pH}$ values between 6 and 8 . These soil $\mathrm{pH}$ values were considered within the range of optimal performance of poplar (Baker and Broadfoot 1979).

\section{Landscape conditions}

Afforestation sites were established on sites ranging in average elevation from $237 \mathrm{~m}$ to $950 \mathrm{~m}$, with an average site elevation of $563 \mathrm{~m}$. When overlain onto the 1998, 12-class land cover dataset developed by Natural Resources Canada (Cihlar et al. 2002), most (83\%) afforestation sites occurred on "herb-dominated, annual graminoid" landscapes. The 1998, 33-class land cover dataset (Cihlar et al. 2002) further indicated that afforestation sites were mainly established on lands classified as "annual graminoid or forb vegetation, croplandwoodland" (35\%) or "annual row-crop forbs and grasses, medium biomass" (28\%).

\section{Discussion}

The temporal and spatial characteristics of afforestation activity in the Prairie region and Alberta can be heavily attributed to the activities of two private forest companies: Vanderwell Contractors and Alberta Pacific Forest Industries (Al-Pac). Vanderwell accounted for all of the spruce trees afforested in the Prairie region between 1990 and 2002. The company lost a significant number of trees to fire during the mid- to late-1990s and offset its losses with afforestation on new areas by planting white spruce trees. Al-Pac can be credited for much of the land base afforested to hybrid poplar. Al-Pac has planted hybrid poplar on approximately 950 hectares, most of which was established during the 1990 to 2002 period (Alberta Pacific Forest Industries 2001a). The cluster of afforestation sites in the vicinity of Lesser Slave Lake and Athabasca correspond to the mill site locations of Vanderwell (Vanderwell Contractors 2004) and Al-Pac (Alberta Pacific Forest Industries 2001b). It appears that forest companies tend to largely engage in afforestation activities within close proximity of their mills as it helps to minimize transportation costs.

Forest companies were not responsible for all afforestation activity, farmers also contributed to the composition and distribution of afforestation activities in the Prairie region. Seen as an alternative cropping opportunity that provides increased flexibility and yields financial returns that are equal to or higher than traditional cereal crop farming (Alberta Agriculture Food and Rural Development 2003), hybrid poplar farming was engaged by Prairie farmers as a means to diversify crops and to provide for more continuous revenues. There was an entrepreneurial business venture that stimulated interest in hybrid poplar farming, and this was largely responsible for much of the afforestation activity in southern Manitoba and southeastern Saskatchewan (Keddy 2004, unpublished data).

The high level of afforestation activity in three ecoregions (Boreal Transition, Mid-Boreal Uplands, and Peace Lowland) suggests that environmental factors, such as climate, soil, and topography, also influence the spatial distribution of afforestation sites. Given that tree growth is responsive to climate (McKenney et al. 2001) and influenced by attributes of the physical environment such as soils, topography, moisture, nutrients, and solar radiation (Kimmins 1997), we would expect some regions to be more suitable than others. Deficiencies in environmental conditions such as moisture and nutrients can be overcome with irrigation and the application of fertilizer, but these practices increase the investment cost. As a result, the spatial distribution of afforestation sites likely follows the spatial trends of the environmental conditions most conducive to the establishment and growth of tree species (moisture, soil $\mathrm{pH}$, solar radiation, etc). This hypothesis is supported by observing that only $4 \%$ of afforestation sites occurred in the mixed and moist-mixed grassland ecoregions, areas known to have relatively low levels of available moisture. A moisture threshold may exist whereby afforestation sites occurred on areas where moisture was sufficient to establish and grow trees that may yield financial returns comparable to traditional agricultural crops.

The analysis of environmental conditions associated with afforestation sites revealed that this threshold corresponds to approximately $342 \mathrm{~mm}$ for mean annual precipitation, $214 \mathrm{~mm}$ for mean growing season precipitation, and/or $-27.3 \mathrm{CMI}$. These values were very similar to the values reported by many practitioners (Berguson 1994, Johnson and Wene 2002, 


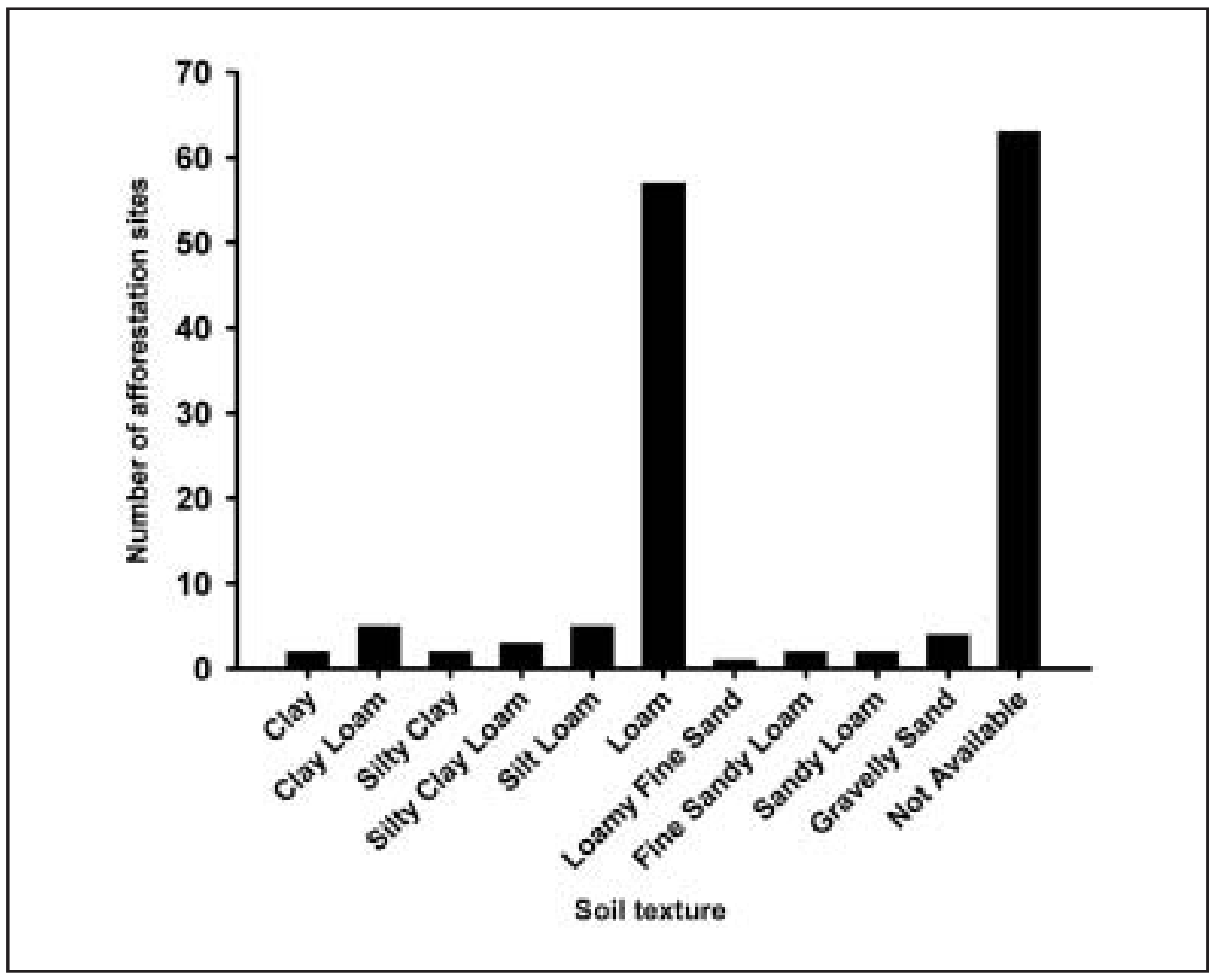

Fig. 6. Distribution of soil texture information by afforestation plot.

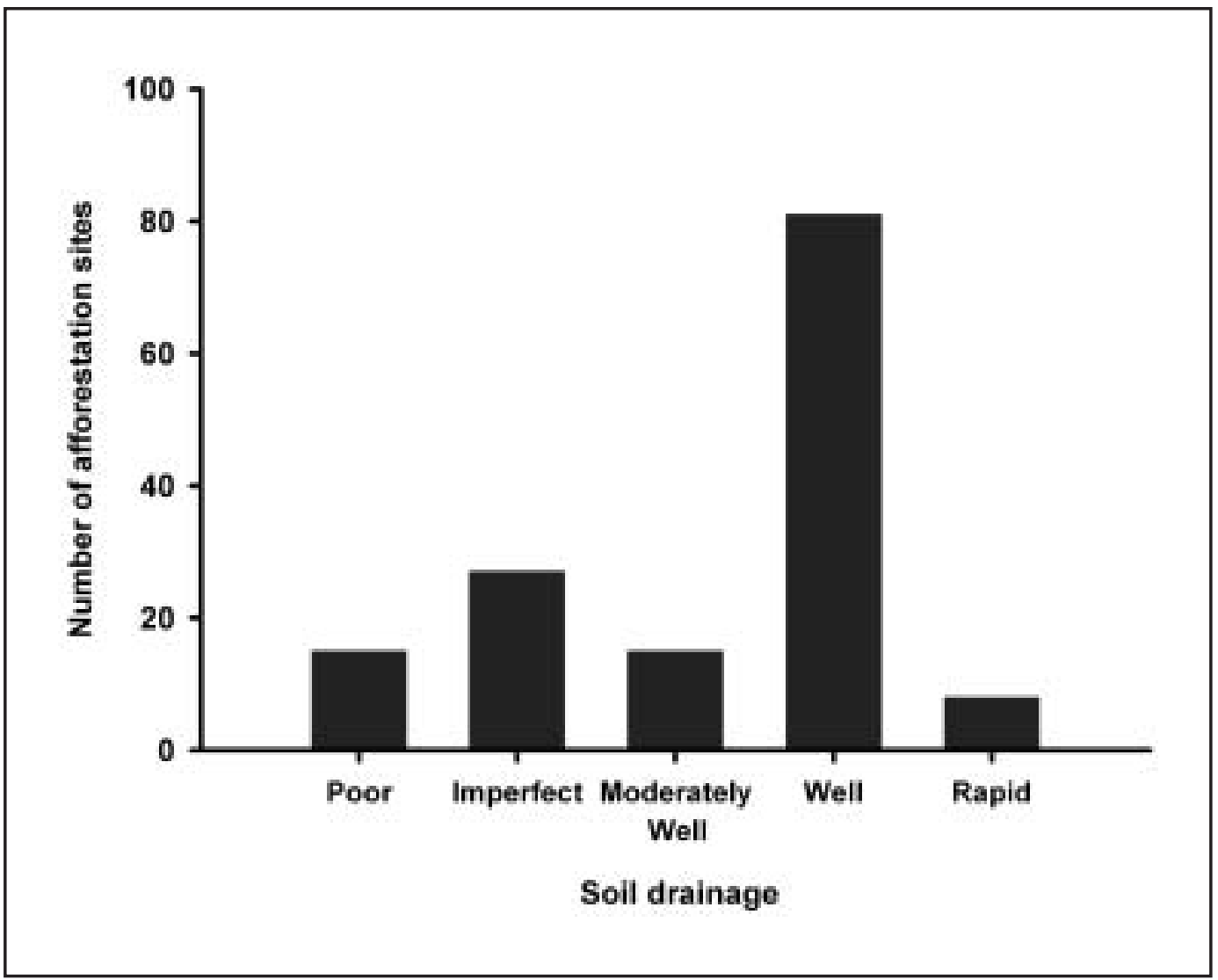

Fig. 7. Distribution of soil drainage information by afforestation plot. 
Schroeder et al. 2003). The spatial distribution of afforestation sites also revealed similarities with other environmental variables, including soil drainage and soil $\mathrm{pH}$. While environmental conditions may not have been the main factor governing the occurrence of afforestation activity, they at least influenced the locations as to where this activity took place in the Prairie Provinces.

\section{Conclusion}

The FAACS backcast for the Prairies helps to estimate and account for the expected carbon stock changes from afforestation/reforestation activities as outlined by Article 3.3 of the Kyoto Protocol. This initiative will also contribute to the overall feasibility assessment of potential large-scale afforestation in Canada. Overall, while relatively little afforestation activity has occurred in the Prairie Provinces since 1990, the trend is increasing. These plantations contribute positively to the natural environment by sequestering $\mathrm{CO}_{2}$ emitted from other sources. These data will be combined with data from other regions to estimate the amount of carbon sequestration expected at the national level, and increasing afforestation efforts are expected in future to contribute significantly to addressing Canada's Kyoto obligations.

This study has compiled the spatial distribution and temporal trends of afforestation between 1990 and 2002 for the Prairie Provinces, and has identified the environmental variables that affect the locations of these afforestation activities due to their influence on tree establishment and growth suitability. Environmental conditions, industrial and entrepreneurial activities, and proximity to mills were identified as factors affecting the composition, timing and spatial distribution of the afforestation activity across the Prairie Provinces. These important findings coupled with the range of environmental conditions found to be associated with afforestation sites are being used to guide the development of an afforestation land suitability index. The land suitability index will, in turn, identify the location and full extent of the land base suited for afforestation across the Prairies, and serve as the basis for its extrapolation across Canada.

\section{Acknowledgments}

Funding for this project was provided by the Canadian Forest Service (CFS) of Natural Resources Canada, and the Government of Canada Action Plan 2000 on Climate Change. Appreciation is expressed to the reviewers of this manuscript: Ed Banfield (CFS - Edmonton), Thomas White (CFS - Victoria), Terry Hatton (CFS - Ottawa), and Jonathan Buttle (CFS - Ottawa).

\section{References}

Alberta Agriculture Food and Rural Development. 2003. Private woodlot enterprises. Agdex 300/830-1.

Agriculture and Agri-Food Canada. 2004. Soil landscapes of Canada. 〈http://sis.agr.gc.ca/cansis/nsdb/slc/index.html> Accessed 2004 July 21.

Alberta Pacific Forest Industries. 2001a. Poplar farms. $<$ http://www.alpac.ca/Fibre_Enhancement/PoplarFarms.htm> Accessed 2004 Mar 1.

Alberta Pacific Forest Industries. 2001b. Poplar farm program. $<$ http://www.alpac.ca/Fibre_Enhancement/PoplarFarms\&Woodlots.htm> Accessed 2004 Mar 1
Baker, J.B. and W.M. Broadfoot. 1979. A practical field method of site evaluation for commercially important hardwoods. USDA Forest Service, Southern Forest Experiment Station, Asheville, N.C., General Technical Report SO-36.

Berguson, W. 1994. Evaluation of land suitability and production economics of hybrid poplar. Final Report, Natural Resources Research Institute, University of Minnesota, Duluth, Minnesota 55811. 33 p. Bibby, J.S., R.E.F. Heslop, R. Hartnup and D.W. Futty. 1988. Land capability for forestry in Britain. British Society of Soil Science.

Brandt, J.P., H.F. Cerezke, K.I. Mallett, W.J.A. Volney and J.D. Weber. 2003. Factors affecting trembling aspen (Populus tremuloides Michx.) health in the boreal forest of Alberta, Saskatchewan, and Manitoba, Canada. Forest Ecology and Management 178: 287-300. Cihlar, J., J. Beaubien and R. Latifovic. 2002. Land cover of Canada 1998. Special Publication, NBIOME Project. Produced by the Canada Centre for Remote Sensing and the Canadian Forest Service, Natural Resources Canada. Available from the Canada Centre for Remote Sensing, Ottawa, Ontario.

Ecological Stratification Working Group. 1995. A national ecological framework for Canada. Agriculture and Agri-Food Canada, Research Branch, Centre for Land and Biological Resources Research and Environment Canada, State of the Environment Directorate, Ecozone Analysis Branch, Ottawa/Hull.

Farr, T.G. and M. Kobrick. 2000. Shuttle Radar Topography Mission produces a wealth of data. American Geophysical Union Eos 81 583-585.

Gosz, J.R. and P.J.H. Sharpe. 1989. Broad-scale concepts for interactions of climate, topography, and biota at biome transitions. Landscape Ecology, 3: 229-243.

Hogg, E. 1994. Climate and the southern limit of the western Canadian boreal forest. Canadian Journal of Forest Research 24: 1835-1845. Hogg, E. 1997. Temporal scaling of moisture and the forestgrassland boundary in western Canada. Agricultural and Forest Meteorology 84: 115-122.

Johnson, W. and E. Wene. 2002. Short rotation forestry of hybrid poplars: choice of land. <http://webhome.crk.umn.edu/ wjohnson/poplars/land.htm> Accessed 2003 May 15

Kimmins, J.P. 1997. Forest ecology: a foundation for sustainable management. Second Edition. Prentice-Hall, Upper Saddle River, New Jersey.

McKenney, D.W., M.F. Hutchinson, J.L. Kesteven and L.A. Venier. 2001. Canada's plant hardiness revisited using modern climate interpolation techniques. Canadian Journal of Plant Science 81: 129-143.

Oullet, C.E. and L.C. Sherk. 1967. Woody ornamental plant zonation II. Suitability indices of localities. Canadian Journal of Plant Science 47: 339-349.

Rabus, B., M. Eineder, A. Roth and R. Bamler, 2003. The shuttle radar topography mission- a new class of digital elevation models acquired by spaceborne radar. Photogrammetric Engineering Remote Sensing 57: 241-262.

Schroeder, W.R. 1998. Determination of poplar wood quality and land suitability. Prairie Farm Rehabilitation Association Shelterbelt Centre, Agriculture and Agri-Food Canada, Project number 97000126, unpublished final report.

Schroeder, W., S. Silim, J. Fradette, J. Patterson and H. de Gooijer. 2003. Detailed site analysis and mapping of agroforestry potential in the northern agricultural zone of Saskatchewan. Agriculture and Agri-Food Canada, Final Report to Saskatchewan Forestry Centre. United Nations Framework Convention on Climate Change. 2004. Text of the Kyoto Protocol. <http://unfccc.int/resource/docs/ convkp/kpeng.pdf> Accessed 2004 June 1.

Vanderwell Contractors. 2004. Contact Information. <http://www. vanderwell.com/html/contact.html> Accessed 2004 Mar 1. 